\title{
REVIVAL TUJUAN PEMBELAJARAN PENDIDIKAN AGAMA ISLAM (PAI) DI ERA REVOLUSI INDUSTRI 4.0
}

\author{
Oleh. \\ Sadam Fajar Shodiq \\ Departement of Islamic Education Universitas Muhammadiyah Yogyakarta \\ sadamfajarshodiq@fai.umy.ac.id
}

\begin{abstract}
Abstrak
Designing a learning, an educator is required to be able to formulate learning objectives clearly and firmly, so that the learning process is systematically well organized so that what is contained in the learning objectives can be as expected. The formulation of learning objectives should not be out of the procedure, must be based on graduate competency standards, core competencies, basic competencies and predetermined indicators. There are four procedures in preparing learning objectives, namely (1) audience; (2) behavior; (3) condition; (4) degree.
\end{abstract}

\section{Keywords: revival, learning objectives, Islamic education, era of industrial revolution 4.0}

\begin{abstract}
Abstrak
Merancang suatu pembelajaran, seorang pendidik dituntut untuk dapat merumuskan tujuan pembelajaran secara jelas dan tegas, sehingga proses pembelajaran terorganisasi secara sistematis dengan baik sehingga apa yang terkandung dalam tujuan pembelajaran dapat sesuai dengan yang diharapkan. Perumusan tujuan pembelajaran tidak boleh keluar dari prosedur, harus didasarkan pada standar kompetensi lulusan, kompetensi inti, kompetensi dasar dan indikator yang telah ditentukan. Ada empat prosedur dalam menyiapkan tujuan pembelajaran, yaitu (1) audiens; (2) perilaku; (3) kondisi; (4) gelar.
\end{abstract}

Kata kunci: kebangkitan, tujuan pembelajaran, pendidikan Islam, era revolusi industri 4.0

\section{A. PENDAHULUAN}

Pendidikan sangat penting untuk suatu negara yang memiliki tujuan dan cakupan yang luas dalam membentuk warga negaranya. Dalam hal ini tentu harus adanya sekolah sebagai tanggung jawab suatu negara agar warga negaranya berhak mendapatkan pendidikan yang menyeluruh. Pendidikan sangat berperan dalam pembentukan karakter bangsa, sebab melalui pendidikan kehidupan manusia akan berjalan sebagaimana mestinya. Agar supaya pola pikir, tingkah laku maupun akhlak anak bangsa itu berjalan sesuai dengan tujuan 
pendidikan yang dirumuskan dalam sistem sekolah. ${ }^{1}$

Upaya untuk menghasilkan pendidikan yang berkualitas selalu dilakukan. Masyarakat mulai menyadari arti pentingnya pendidikan bagi kehidupan mereka. Karena pendidikan merupakan tolak ukur seseorang itu memiliki pengetahuan yang luas maupun karakter yang lebih baik dalam berhubungan dengan masyarakat. Seseorang yang mempunyai pengetahuan dan memberi hasil dimasyarakat lebih dianggap bermakna daripada yang lain. Oleh sebab itu, sekolah menjadi tempat untuk mendapatkan pedidikan yang tidak hanya mengajarkan kepada teori namun harus ada pendidikan karakter juga untuk membentuk anak bangsa yang bermoral, sehingga perlu menata pembelajaran yang bermutu agar mampu memberi hasil kepada masyarakat.

Sebab, bagaimanapun juga pembelajaran adalah akar dari pendidikan. Untuk itu, ia membutuhkan desain pembelajaran yang jelas dan berkelanjutan serta berkualitas. ${ }^{2}$

Dalam mendesain sebuah pembelajaran, seorang pendidik diharuskan mampu merumuskan tujuan pembelajaran dengan jelas dan tegas, agar dalam proses pembelajaran tersistematis dengan baik sehingga apa yang ada dalam tercantum dalam tujuan

1 Silfia Hanani, Sosiologi Pendidikan Keindonesiaan, Ar-Ruzz Media, Jogjakarta, 2016, hlm. 15.

2 Asmaun Sahlan dan Angga Teguh

Prastyo, Desain Pembelajaran Berbasis Pendidikan Karakter, Ar-Ruzz Media, Jogjakarta, 2016, hlm 7.

pembelajaran bisa sesuai dengan apa yang diharapkan.

Dewasa ini perubahan sosial begitu cepat terjadi, sementara kualitas dari anak bangsa begitu menurun drastis dengan kehilangan karakter pendidikan itu sendiri. Lunturya jati diri anak bangsa yang terpelajar dan terdidik menyebabkan realitas sosial yang tidak sesuai dengan harapan kehidupan. Misalnya, semakin maraknya perkelahian dan moralitas yang sudah diabaikan semakin tidak sesuai dengan harapan sekolah atau pendidikan. ${ }^{3}$

Berkembangnya persoalan kebangsaan seperti sekarang ini dan melunturnya karakteristik kebangsaan salah satu yang mempengaruhinya adalah melemahnya peran pendidikan dalam membangun moralitas dan mentalitas bangsa, termasuk melemahnya peran pendidikan keagamaan. Padahal, peran pendidikan keagamaan dilintas sejarah bangsa sudah terbukti sebagai pembangun karakteristik bangsa pada mulanya. Oleh sebab itu, pendidikan keagamaan tidak dapat diabaikan dalam membawa masa depan bangsa.Pendidikan keagamaan merupakan sarana pembangun mentalitas, sosial, dan jati diri anak bangsa di negara yang berpenduduk beragama ini. Keterabaian dalam membenah pedidikan keagamaan telah nyata melahirkan sebuah kebangsaan

${ }^{3}$ Silfia Hanani, Sosiologi
Pendidikan...,hlm. 12. 
yang rapuh dan mengalami distorsi yang sangat merugikan masa depan bangsa. ${ }^{4}$

Oleh sebab itu, pendidikan memiliki peran yang sangat penting dalam membangun sumber daya manusia yang kompetitif dan mampu bersaing di tengah percaturan pertemuan antar bangsa di era modern ini. Pendidikan harus mampu mempersiapkan generasi yang berkualitas dan kritis dalam menghadapi tantangan maupun perubahan-perubahan yang terjadi. Maka pendidikan adalah kunci kemajuan, semakin baik kualitas pendidikan yang diselenggarakan suatu bangsa akan semakin baik juga kualitas kehidupan bangsa tersebut. ${ }^{5}$

\section{B. LANDASAN TEORI}

\section{Definisi Tujuan Pembelajaran}

Tujuan pembelajaran adalah suatu rumusan terencana yang harus dikuasai siswa agar proses belajarnya berhasil. Tujuan pembelajaran merupakan suatu gambaran yang wajib dimiliki siswa kemudian disampaikan dalam bentuk pernyataan sebagai akibat dari hasil pembelajaran yang bisa diamati dan diukur. Dalam perumusan tujuan pembelajaran harus jelas, karena merupakan bahan tolak ukur dari proses pembelajaran yang diharapkan siswa

\footnotetext{
${ }^{4}$ Samiudin. (2016). Peran metode untuk mencapai tujuan pembelajaran. Jurnal Studi Islam, 11(2), 94-97.

5 Budi Haryanto, "Perbandingan Pendidikan Islam di Indonesia dan Malaysia", Adabiyah Jurnal Pendidikan Islam. Vol. 1 No. 1, September 2015, hlm. 80.
}

mampu berhasil dalam proses belajar itu sendiri.

Dalam proses pembelajaran, apabila tingkah laku siswa tidak sesuai dengan apa yang diharapkan dalam tujuan pembelajaran, maka rumusan dari pembelajaran itu belum tercapai. Sebab, tujuan pembelajaran mencakup seluruh tingkah laku siswa, baik berupa pengetahuan, keterampilan maupun norma.

Perumusan tujuan pembelajaran juga tidak boleh keluar dari prosedur, harus berdasarkan standar kompetensi lulusan, kompetensi inti dan kompetensi dasar serta indikator yang sudah ditentukan dan termuat dalam RPP. Sebab, tujuan pembelajaran merupakan acuan pendidik dan sebagai evaluasi pembelajaran agar tercipta peserta didik yang dicita-citakan.

\section{Pendidikan agama Islam dari masa ke masa}

Jika melihat kepada maksud yang di utarakan di dalam PP. No. 55 tahun 2007, maka seluruh kegiatan pendidikan yang dapat membuat anak didik menjadi dapat mengetahui dengan benar dan juga dapat menerapkan agama melalui pengetahuannya itu adalah pendidikan Agama. ${ }^{6}$ Awal mulanya di Indonesia pendidikan agama Islam terbengkalai dan tidak mendapatkan perhatian sama sekali,

6 Lembaga Pendidikan Fakultas Tarbiyah, Bahan Ajar DIKLAT Profesi Guru, Sertifikasi Guru, Pengawas dalam Jabatan Kuota 2009,(Surabaya: Fakultas Tarbiyah, 2009), hlm. 103. 
karena pada awal-awal ketika Indonesia masih dijajah oleh bangsa asing pendidikan di Indonesia sangat tergantung kepada bangsa penjajah tersebut. Maka pada masa itu pendidikan tidak bertujuan untuk membentuk peserta didik yang cinta terhadap bansanya sendiri, namun lebih diarahkan kepada potensi untuk dapat melancarkan kepentingan penjajah tersebut. Selain itu, bangsa penjajah juga memiliki tujuan untuk menyebarkan misi agama mereka, yaitu menyebarkan agama kristen. Maka dapat difahami bahwa pada masa awalawal sebelum Indonesia merdeka pendidikan masih sangat dipengaruhi para penjajah dan belum bisa mandiri diatur oleh bangsa kita sendiri dan pendidikan agama Islam belum dilaksanakan dengan baik.

Setelah Indonesia merdeka, pada masa orde lama pendidikan agama Islam terlihat mulai diperhatikan. hal ini dapat diketahui dengan adanya kurikulum yang mengatur pelaksanaan pendidikan agama Islam. Yaitu diatur di dalam SKB dua menteri (Menteri PP dan k dan Menteri Agama) pada tahun $1946 .^{7}$ Selain itu Departemen Agama juga mengusahakan untuk membentuk kurikulum agama Islam yang nantinya diharapkan agar dilaksanakan baik itu di sekolah ataupun di pesantren. Maka dihasilkanlah kurikulum agama yang memuat pendidikan agama tersebut.

\footnotetext{
Ahmad Dhaifi, "Perkembangan Kurikulum PAI di Indonesia", Edureligia, Vol 01, No 01, 2017, hlm. 78.
}

Pada masa orde baru perubahan kurikulum juga dilakukan. Perubahan kurikulum bertujuan untuk menyempurnakan kurikulum yang sebelumnya. Namun, pada pendidikan agama kurikulumnya masih sama dengan kurikulum yang sebelumnya. Mulai ada perubahan dalam kurikulum pendidikan agama dari kurikulum agama sebelumnya adalah pada kurikulum tahun 1975. Hal ini adalah berdasarkan adanya SKB tiga menteri, yaitu Menteri Agama, Menteri dalam negeri dan Menteri P\&K dan penyusunan kurikulum madrasah 1975, maka pendidikan agama memiliki porsi $30 \%$, sedangkan pendidikan umum memiliki bagian $70 \% .^{8}$

Kemudian setelah adanya kurikulum 1975 tersebut, terbentuk lagi kurikulum tahun 1994. Kurikulum tahun 1994 ini memuat pemaduan antara kurikulum-kurikulum sebelumnya. Hal yang paling penting pada kurikulum ini adalah adanya Undang-Undang SISDIKNAS no 2 tahun 1989 yang memuat poin penting bahwa madrasah merupakan lembaga yang memiliki ciri khas Islam. Sehingga muatan kurikulum struktur dan konsepnya satu alur dengan nilai-nilai agama Islam. ${ }^{9}$

Selanjutnya, pendidikan agama Islam pada masa reformasi. Masa reformasi merupakan masa dimana wacana demokrasi semakin berkembang pesat yang mana masa sebelumnya, yaitu masa orde baru terkenal dengan keotoriterannya. Namun di sisi lain,

${ }^{8}$ Ibid, hlm. 80.

${ }^{9}$ Ibid, hlm. 81. 
pendidikan agama Islam masa awal reformasi masih belum terkena perubahan.kebijakan-kebijakan dalam bidang pendidikan terlihat masih menggunakan kebijakan pemerintah orde baru. Namun demikian kebijakankebijakan pada pendidikan agama Islam yang merupakan hasil dari usaha pemerintah juga patut untuk dihargai. Jadi, secara ringkasnya adalah bahwa pelaksanaan pendidikan agama Islam pada awal masa reformasi ini tidak jauh berbeda dengan masa sebelumnya yaitu masa orde baru. ${ }^{10}$

Pada masa reformasi ada tiga kali penetapan kurikulum. Pertama adalah kurikulum 2004. Pada kurikulum 2004 ini menuntut pelaksanaan pendidikan agama Islam, sehingga mau tidak mau madrasah harus menetapkan basis kompetensi dari kurikulum 2004 ini. kedua adalah penetapan kurikulum 2006 atau biasa disebut dengan KTSP (kurikulum tingkat satuan pendidikan). Pelaksanaan pendidikan agama Islam pada kurikulum ini dijelaskan dan diatur oleh Kementrian Agama di dalam kurikulum agama yang disahkannya. Peraturan Menteri Agama no 2 tahun 2008 tersebut adalah berisi tentang SKL (standar kompetensi lulusan) dan standar isi pendidikan agama Islam.

Adapun yang ketiga adalah kurikulum tahun 2013 atau biasa disebut dengan kurtilas. Pendidikan agama Islam pada kurikulum ini lebih mengedepankan kepada pendidikan karakter. Jadi,

\footnotetext{
${ }^{10}$ Baderiah, "Pendidikan Islam Masa Reformasi” Al-Iqdam, Vol 2, No. 4, hlm. 83.
}

pendidikan agama Islam pada kurtilas ini bertujuan untuk membentuk peserta didik menjadi pribadi yang memiliki karakter yang sesuai dengan nilai-nilai ajaran agama Islam dan memiliki wawasan lokal. Kurikulum ini juga bertujuan untuk menjadikan suasana pendidikan yang ceria bagi para peserta didik, sehingga mereka dapat merasakan suasana belajar yang lebih bersahabat.

Dari berbagai uraian yang telah dipaparkan di atas, maka dapat diketahui bahwa kurikulum pendidikan agama Islam dari masa ke masa mengalami berbagai macam perubahan. Dari perubahan-perubahan tersebut maka diharapkan pendidikan agama Islam senantiasa berkembang kepada kondisi yang lebih baik dari sebelumnya. Sehingga tujuan dari terselenggaranya pendidikan agama Islam dapat tercapai dengan semaksimal mungkin.

\section{PEMBAHASAN \\ 1. Tujuan pembelajaran}

Menurut Samiudin tujuan merupakan satu titik yang akan diraih dalam proses kegiatan belajar mengajar sehingga bagaimanapun kegiatan belajar mengajar berlangsung tujuan tersebut akan menjadi pedomannya. ${ }^{11}$ Sedangkan arti pembelajaran berdasarkan yang dikemukakan oleh Gagre dan Briggs sebagaimana yang dikutip oleh Samiudin adalah susunan kejadian, peristiwa dan keadaan yang memang dibuat sedemikian

11 Samiudin, "Peran metode untuk mencapai tujuan pembelajaran", Studi Islam, Vol 11, No. 2, 2016, hlm. 118. 
rupa untuk mengkontrol peserta didik agar kegiatan belajarnya menjadi terlaksana dengan lancar. ${ }^{12}$

Dikatakan bahwa adanya tujuan pembelajaran menjadikan kegiatan belajar menjadi lebih terarah, lebih efisien dan lebih maksimal. Menurut Benyamin S. Bloom sebagaimana yang dikutip oleh Hamzah B. Uno di dalam bukunya yang berjudul Perencanaan Pembelajaran, bahwa tujuan pembelajaran bisa diklasifikasi menjadi tiga bagian wilayah,yaitu (1) wilayah kognitif, (2) afektif, (3) Psikomotorik. ${ }^{13}$

Pada wilayah kognitif tujuan pembelajarannya dibahas berkaitan dengan perjalanan mental dari level pengetahuan saja menuju kepada level yang lebih diatasnya, yaitu level evaluasi. Kemudian pada wilayah afektif adalah berkaitan dengan nilai, sikap, apresiasi atau penghargaan, dan pembiasaan perasaan bersosial. Adapun psikomotor maka tujuan pembelajaran akan dikaitkan dengan skill atau keterampilan yang bersifat motorik. ${ }^{14}$

\section{Target Pembelajaran Agama Islam}

Pembelajaran Agama Islam adalah satu dari sekian mata pelajaran yang diajarkan di dunia akademik, namun akan berbeda ketika pembelajaran ini diajarkan di sekolah yang bukan berbasis Islam. Pada sekolah yang berbasis Islam

${ }^{12}$ Ibid, hlm. 115.

13 Hamzah B. Uno, Perencanaan Pembelajaran, Jakarta: PT Bumi Aksara,2008, hlm. 35.

${ }^{14}$ Ibid, hlm. 30. tentu pembelajaran ini akan jauh lebih terperinci, nantinya akan dipecah menjadi beberapa bagian lagi seperti: pembelajaran aqidah, akhlak, al-Qur'an, hadis dan mata pelajaran yang berinduk kepada pelajaran Agama Islam. Pelajaran Agama Islampun juga akan diajarkan di sekolah-sekolah yang bukan berbasis Islam, tentunya akan dikemas lebih ringkas. Jika kita cermati akan sangat menarik, hal ini dikarenakan tujuan apa yang ingin dicapai dalam pembelajaran Agama Islam yang diberikan kepada peserta didik.

Secara umum tujuan pendidikan Agama Islam yang diharapkan ialah mampu mencetak para intelektual yang beriman dan bertaqwa sehingga mampu menjalankan syariat Islam sesuai dengan tuntunan al-Qur'an dan sunnah. Selain itu tujuan yang dicapai ialah mampu menjadikan peserta didik memiliki akhlak, budi pekerti yang mulia sesuai norma-norma yang ada di masyarakat. Sehingga dari pembelajaran Agama Islam mengarahkan peserta didik untuk memiliki sifat religiusitas serta nasionalisme, berguna bagi agama dan bangsanya.

Pendidikan Agama Islam jika kita mengacu pada peraturan menteri pendidikan dan kebudayaan setidaknya mampu menjadikan manusia yang senantiasa meningkatkan kualitas keimanan dan ketaqwaannya serta mampu berakhlak mulia dalam kehidupannya, akhlak mulia yang meliputi moral, etika, dan budi pekerti, 
sebagai implementasi pendidikan. ${ }^{15}$ Tentunya ketika melihat dari maksud pemerintah yang dituangkan dalam peraturan menteri tadi setidaknya ada point terpenting yang ingin dicapai yaitu pendidikan karakter.

Pendidikan karakter tidak telepas dari pembelajaran Agama Islam, karena akan menjadi kesatuan yang saling berhubungan. Ketika Agama Islam mengajarkan nilai-nilai akhlak mulia, maka pendidikan karakter menginginkan peserta didiknya bukan hanya pintar dalam ilmu pengetahuan namun juga memiliki moral, etika serta budi pekerti yang baik. Sehingga menghasilkan manusia-manusia yang unggul bukan hanya dalam hal pengetahuannya akan tetapi memiliki sisi religius yang bagus juga.

Dalam undang-undang disebutkan bahwasannya pendidikan karakter memiliki posisi yang sangat penting dalam dunia pendidikan Indonesia, sebagai mana undang-undang Nomor 20 Tahun 2003:

"Pendidikan nasional berfungsi mengembangkan kemampuandan membentuk watak serta peradaban bangsa yang bermartabat dalam rangka mencerdaskan kehidupan bangsa, bertujuan untuk berkembangnya potensi peserta didik agar menjadi manusia yang beriman dan bertakwa kepada tuhan yang maha esa, berakhlak mulia, sehat,

\footnotetext{
15 Permendikbud RI No. 21 Tahun 2016, Tentang Standar Isi Untuk SatuanPendidikan Tingkat Dasar Dan Menengah, hlm. 2.
}

berilmu, cakap, kreatif, mandiri, dan menjadi warga negara yang demokratis serta bertanggung jawab". ${ }^{16}$

Penanaman nilai-nilai karakter yang diajarkan bukan hanya menjadikan peserta didik dalam hal perilakunya bagus tetepi lebih dari itu peserta didik juga mampu menjadi manusia yang berbudaya, memiliki sifat nasionalis, yang nantinya dapat menangkal bahkan tidak terlibat pada permasalahan bangsa akan tetapi menjadi bagian memberantas masalah moral bangsa. Hal ini merupakan kejadian yang rill bagi bangsa kita, ketika di media cetak maupun elektronik memberitakan banyak tindak kriminallitas di bangsa ini yang notabanenya negara ini mayoritas beragama Islam. Belum lagi permasalahan para wakil-wakil rakyat yang tentu mereka bukan orang sembarangan, mereka orang-orang terpilih yang memiliki pengetahuan yang mumpuni namun tidak dalam moral yang baik akhirnya beberapa dari mereka menyalah gunakan jabatannya. Hal seperti inilah yang membuat pentingnya pendidikan Agama Islam sebagai bagian dalam mensukseskan pendidikan karakter.

Keberhasilan pada pendidikan Agama Islam tentu akan bisa diukur dengan evaluasi-evalusi yang dilakukan oleh sekolah, namun akan berbeda ketika pendidikan karakter dilakukan tolak ukur keberhasilannya bukan dilihat dari nilai atau bisa dikatakan tidak bisa diukur

16 Undang-Undang No. 20 Tahun 2003, Tentang Sistem PendidikanNasional, hlm. 8. 
dengan nilai, akan tetapi tingkat keberhasialannya akan dilihat dari output kepribadian setiap peserta didik, dalam kehidupannya di masyarakat. Bukan hanya intelektualnya yang bagus tapi, dalam pendidikan karakter masyarakatlah yang akan menilai bagaimana perilakunya sehari-hari, paling tidak lingkup kecilnya ialah keluargannya sendiri.

\section{Prosedur Penyusunan Tujuan Pembelajaran}

Dalam menyusun tujuan pembelajaran setidaknya ada empat faktor yang perlu diperhatikan menurut Hamzah B. Uno (2008) Sehingga tujuan yang ingin dicapai dapat terlaksana sebagaimana mestinya.

\section{a. Audiens}

Prosedur yang pertama adalah audiens yaitu salah satu awal prosedur penyusunan tujuan pembelajaran terpenting ialah adanaya audiens dalam hal ini jika peserta didik bisa jadi murid ataupun dalam dunia perkuliahan ialah mahasiswa.

\section{b. Behaviour}

Kedua dalam penyusunan tujuan pembelajaran tahapan ini perlu, karena agar mengetahui sejauh mana perubahan yang telah dilakukan peserta didik dalam tahapan pembelajaran. Hal ini sangat penting sebagai tolak ukur nantinya serta evalusi dalam tujuan pembelajaran. Contoh: adanya evalusi di sekolah adalah salah satu tahapan agar pendidik mengetahui batas kemampuan siswa.

\section{c. Condition}

Condition atau kondisi juga bagian yang perlu diperhatikan dalam proses pembelajaran sehingga tercapainya tujuan pembelajaran yang diinginkan. Kondisi ini bisa dirancangkan sebelum pembelajaran dilakukan, namun kadang kala ada hal yang tidak diharapkan terjadi, maka seorang pendidik harus mampu mengatasi kondisi ini. Contoh: dosen bisa mengajar dalam keadaan apapun baik tidak ada lcd, mati lampu, pendidik akan siap setip waktu. Pendidik juga perlu memperhatikan setiap peserta didiknya dalam pengajarannya apa saja yang sudah ditangkap peserta didik misalnya: dengan diskusi.

\section{d. Degree}

Proses yang juga tidak terlepas pentingnya adanya batasan minimum yang harus dicapai peserta didik, sehingga hal ini perlu diukur dalam mencapai tujuan pembelajaran yang diinginkan.

Langkah-langkah yang ada pada bagian atas tadi sering dikenal dengan pormasi ABCD, setidaknya membantu para guru ataupun dosen untuk mengingatnya sehingga dapat dengan mudah menerapkannya dalam rangka mencapai tujuan pembelajaran yang di inginkan. Selain itu sebenarnya masih banyak teori ataupun langkah-langkah yang dikemukakan para ahli, jika kita coba mencari kemudian membaca akan banyak sekali macam ragam teori yang dikemukakan para ahli tersebut. Teori merekapun tentu memiliki corak dan kelebihannya masing-masing, sama halnya yang kami kemukakan pada paper 
ini, ini adalah sebagian kecil teori dari banyaknya teori para ahli.

\section{SIMPULAN}

Berdasarkan hasil pemaparan dan analisis di atas, maka dapatdisimpulkan antara lain:

1. Tujuan pembelajaran tidak akan tercapai jika dari awal prosedur penyusunannya tidak sesuai antara harapan dengan tahapan-tahapan yang harus dilalui.

2. Pendidikan Indonesia dan Jerman memiliki kesamaan yakni dipengaruhi oleh Negara dan Agama

3. Sejak awal disusunnya kebijakan pendidikan di Indonesia memiliki tujuan membentuk peserta didik yang berkarakter, yang pada akhirnya pendidikan karakter menjadi sebuah kebijakan yang harus ada pada kurikulum.

4. Tujuan pembelajaran memiliki peran penting dalam meningkatakan kemampuan peserta didik, sedangkan tujuan pembelajaran PAI menjadikan peserta didik bukan hanya berpengetahuan tinggi namun juga memiliki budi pekerti yang mulia.

5. Untuk mengetahui tercapai tidaknya tujuan pendidikan maka perlunya dari awal prosedur penyusunan yang sesuai yang kemudian pula adanya evaluasi yang dilakukan.

\section{DAFTAR PUSTAKA}

Ainiyah, Nur, 2013, "Pembentukan Karakter Melalui Pendidikan Agama Islam", Al-Ulum, Vol. 13, No. 1.

Baderiah,"Pendidikan Islam Masa

Reformasi” Al-Iqdam, Vol 2, No. 4.

B. Uno, Hamzah, 2008, Perencanaan

Pembelajaran, Jakarta:PT Bumi

Aksara.

Dhaifi, Ahmad, "Perkembangan Kurikulum PAI di Indonesia", Edureligia, Vol 01, No01.

Hanani, Silfia, 2016, Sosiologi Pendidikan Keindonesiaan, Yogyakarta: Ar-Ruzz Media.

Haryanto, Budi, 2015, "Perbandingan

Pendidikan Islam Di Indonesia dan Malaysia", Adabiyah Jurnal Pendidikan Islam, Vol. 1 No. 1.

Isri, Saifullah, 2015,'Konsep Pendidikan

Jerman dan Australia; Kajian

Komparatif danAplikatif terhadap Mutu Pendidikan Indonesia”, Jurnal Pendidikan Islam, Vol IV, No 1.

Koesoema, Doni, 2015, Pendidikan Karakter utuh dan menyeluruh, Jakarta: Kanisius.

Lembaga Pendidikan Fakultas Tarbiyah, 2009, Bahan Ajar DIKLAT Profesi GuruSertifikasi Guru, Pengawas dalam Jabatan Kuota 2009, Surabaya:Fakultas Tarbiyah.

Sahlan, Asmaun dan Prastyo, Angga Teguh, 2016, Desain Pembelajaran BerbasisPendidikan Karakter, Yogyakarta: Ar-Ruzz Media. 
Samiudin, 2016, "Peran metode untuk mencapai tujuan pembelajaran", Studi Islam, Vol11, No. 2.

Suyadi, 2014, "Pelaksanaan Pembelajaran PAI di SMK Negeri

1 Lais Kecamatan LaisKabupaten Musi Banyuasin, Palembang: UIN Raden Patah.

Permendiknas RI No. 22 Tahun 2006, Tentang Standar Isi Untuk Satuan PendidikanTingkat Dasar Dan Menengah.

Undang-Undang No. 20 Tahun 2003, Tentang Sistem Pendidikan Nasional.

Wagiran, 2010, "Implementasi Pendidikan Karakter dalam Menyiapkan Tenaga

KerjaKejuruan Menghadapi

Tantangan Global", Yogyakarta:

Lembaga Penelitian UNY. 